\title{
НОВ ПОГЛЕД ВЪРХУ МЕЖДУСЛАВЯНСКИТЕ ЕЗИКОВИ КОНТАКТИ
}

\author{
Iliana Genew-Puhalewa \\ Uniwersytet Śląski w Katowicach
}

Елена Крейчова. Славянският Вавилон. За интерференцията между славянските езици. София: Парадигма, 2016, 105 стр.

Новоизлязлата монография на Елена Крейчова носи метафоричното заглавие Славянският Вавилон, с което, препращайки към библейското сказание за възникването и същевременно объркването на езиците, щрихира образа на съвременния междуславянски езиков контакт. Предмет на изследване в книгата е интерференцията между славянските езици (така звучи и нейното подзагалвие), и в частност езиковият трансфер между българския и чешкия език. От позицията на дългогодишен преподавател по практически български език в Масариковия университет в Бърно и действащ преводач на художествена и специализирана литература, авторката мотивира изследователския си избор, определяйки интерференцията като явление, което съпътства още първите крачки в обучението по чужд език, и се проявява особено силно, когато чуждият е генетично близък с първия език (с. 59). Така замислено, изследването носи потенциални ползи преди всичко за глотодидактиката и професионалната подготовка на преводачи - както в теоретичен, така и в практически план.

Монографията включва предговор, 8 глави, заключение и богата библиография. Неголемият обем на публикацията е нейно достойнство, произтичащо от умението на Е. Крейчова да представя тези проблеми сбито, с акцент върху найсъщественото.

Предговорът ситуира изследването в широк езиковедски контекст - в контекста на психолингвистиката, приложната лингвистика и езиковата прагматика. 
Освен това авторката си служи и с утвърдени постановки и методи на съпоставителната лингвистика, дериватологията и морфологията.

В първия раздел се постулират основните понятия (респ. термини) на изследването: първи език, втори език, усвояване на първия / втория език. Изтъкват се разликите при усвояването на първия и на втория език (и на всеки следващ чужд), а също така ролята на първия език в процеса на обучението. В хронологична последователност се проследява еволюцията на възгледите по този въпрос в рамките на различните направления в лингвистиката (с. 10-12). Особено внимание е посветено на фундаменталното за труда понятие интерференция, като са синтезирани съществуващите концепции за него както в англоезичната литература, така и в славянското езикознание, за периода от 2о-те години на XX век (в работите на И. Епщайн и А. Мейе) до днес (с. 16 и сл.). Интерференцията се разглежда като сложно езиково явление и респективно като многоаспектен лингвистичен проблем. За неговото изучаване Е. Крейчова смята за необходимо да хвърли светлина върху понятието трансфер, върху видовете трансфер и видовете интерференция. Последната може да бъде междуезикова и вътрешноезикова, явна и скрита, проактивна и ретроактивна, статична и динамична (с. 18 и сл.). Разисквайки проблема за интерференцията според проявите ѝ на различните езикови нива (фонологично, лексикално, граматично), авторката въвежда понятието интерферентна грешка, като се позовава на добилия популярност в съпоставителното езикознание метод анализ на грешките (англ. error analysis).

Проблемът за т.нар. лъжливи приятели на преводача (тук неверни приятели на преводача) се явява централен за изследването и на него е посветен един раздел. Авторката изтъква, че въпреки наличието на множество разработки (цитирани в библиографията), все още липсва обзорен труд, който да изучава въпроса в мултиезичен славистичен план (с. 35). В рамките на няколко подраздела Е. Крайчова дава своя принос за обогатяването на лингвистичното знание в тази област, като разизква семантичния аспект на подвеждащите езикови единици с оглед на явленията полисемия, омонимия и паронимия.

При по-нататъшното изучаване на проблема в дълбочина авторският избор на Е. Крейчова пада върху въпроса за деривацията на деятелни съществителни имена в контекста на езиковата интерференция между българския и чешкия език. Вниманието на авторката е насочено към определени словообразувателни форманти в чешкия език, които имат свои етимологични еквиваленти в български (-tel, -č, -ce, -ec, -nik, -čí-ak, -or / -(á)tor, -ant, -ent, -l и съответно -ар, -ач, -ец, -ник, -тел, -атор, -ант / -ент, -льо, -ла). Потенциалните проблемни зони (с. 51), са подложени на конфронтативен анализ, в който се отчита критерият продуктивност / непродуктивност на 
словообразувателния тип. Изводите от анализа на системните данни са съпроводени от интересни коментари, почиващи на личните наблюдения на авторката от работата ѝ като университетски преподавател.

Друга област от езика, която Е. Крейчова разглежда като поле за изява на интерференцията между два славянски езика, е граматичният род на лексеми с различен произход: славянски и чужд (гръцки, латински, френски). Тук се разискват т.нар. колебания в рода на съществителното име в рамките на езиковите системи на българския и чешкия с оглед на интерфериращо влияние на първия език върху езиковите умения на изучаващите съответния славянски език като втори.

В раздела, озаглавен „Изгубени в превода“, или още по въпроса за българскочешките „подводни камъни“ при превод, авторката насочва вниманието си към един специфичен проблем на обучението в специалността Балканистика в Масариковия университет в Бърно - студентите чехи или словаци изучават едновременно два славянски езика от Балканския полуостров: български, сръбски и/или хърватски. Емпиричен материал, ексцерпиран от студентски преводи с изходен език чешки и език-цел български, е изследван по метода на анализа на грешките. Голяма част от установените интерфереми или деформации, както доказва Е. Крейчова, се дължат на влиянието на изучавания втори славянски език. Грешките се описват по езикови равнища: графични, правописни, лексикални, морфологични, синтактични.

Интерес предствлява и последният раздел на монографията Славянският $\mathrm{Ba}$ вилон, който е посветен на българската реч на българите извън България. Обект на наблюдение е интернет форум на българки, живеещи в Чехия, като цел на наблюдението е да се направят изводи за устойчивостта на майчиния език (българския) в чуждоезикова среда (с. 83 и сл.). Е. Крейчова стига до заключението, че в дадената специфична комуникативна среда интерференцията се явява умишлено използвано средство, подчинено на определена цел на общуването. Авторката смята, че лексикалните интерференции, които са най-многобройни и ярки, представляват осъзната стратегия при субординиран билингвизъм, която служи за по-добро разбиране и улесняване на комуникацията (с. 92).

Очаквам актуалността на темата, автентичността на анализирания материал и като цяло научните качества на рецензираната тук монография да привлекат вниманието както на специалистите, така и на славяните, изучаващи български език. 